\title{
Study of the carotenoid composition in membrillo, guanabana toreta, jobo and mamey fruits
}

\author{
Daniele Giuffrida $^{1, \star}$, Dania Menchaca ${ }^{2}$, Paola Dugo $^{3,4,5}$, Paola Donato ${ }^{1}$, Francesco Cacciola ${ }^{1}$ \\ and Enrique Murillo ${ }^{2}$ \\ 1 Università degli Studi di Messina, Dipartimento di Scienze dell’Ambiente, della Sicurezza, del Territorio, degli Alimenti e della Salute, Viale \\ F. Stagno d'Alcontres 31, 98166, Messina, Italy \\ 2 Departamento de Bioquimica, Facultad de Ciencias Naturales Exactas y Tecnologia, Universidad de Panama, Panama \\ 3 Università degli Studi di Messina, Dipartimento di Scienze del Farmaco e dei Prodotti per la Salute, Viale Annunziata, 98168, Messina, Italy \\ 4 Università Campus Bio-Medico di Roma, Via Alvaro del Portillo 21, 00128, Roma, Italy \\ 5 Chromaleont s.r.l. A start-up of the University of Messina, Dipartimento di Scienze del Farmaco e dei Prodotti per la Salute, Italy
}

Received 4 September 2014 - Accepted 29 January 2015

\begin{abstract}
Introduction. Many tropical fruits have great health potential due to the possible presence of bioactive phytochemicals. Natural food composition databases are very important sources of information relative to natural food biodiversity and nutritional properties. The objective of this study was to report for the first time on the native carotenoid composition of the fruit of four tropical species from Panama. Materials and methods. Fully mature fruit were collected in Panama and analyzed by HPLC-DAD-APCI-MS, after carotenoid extraction with acetone. Results and discussion. The carotenoid composition had never been previously reported for two of the investigated fruits, membrillo (Gustavia superba) and guanabana toreta (Annona purpurea). In membrillo, 5 different carotenoids were detected; the content of total carotenoids was $318.6 \mu \mathrm{g} \mathrm{g}^{-1}$ fresh weight (fw), with $\beta$-carotene showing a relative abundance of $75.3 \%$. In guanabana toreta, 11 different carotenoids were detected; the total carotenoid content was $48.3 \mu \mathrm{g} \mathrm{g} \mathrm{g}^{-1} \mathrm{fw}$, with $\beta$-carotene and zeaxanthin showing a relative abundance of $26.9 \%$ and $27.5 \%$, respectively. In jobo (Spondias mombin), 11 different carotenoids were detected; the total carotenoid content was $45.8 \mu \mathrm{g} \mathrm{g}^{-1} \mathrm{fw}$, with $\beta$-cryptoxanthin, $\alpha$-carotene and $\beta$-carotene showing a relative abundance of $25.4 \%, 10.5 \%$ and $8.5 \%$, respectively. In mamey (Mammea americana), 16 different carotenoids were detected; the total carotenoid content was $145.2 \mu \mathrm{g} \mathrm{g}^{-1} \mathrm{fw}$; in particular, 10 different violaxanthin fatty acid diesters, of both $\mathrm{cis}$ and trans isomers, were determined. Conclusion. The consumption of the fruit studied should be promoted both locally and abroad, because of the reported presence of these health-promoting phytochemicals.
\end{abstract}

Keywords: Panama / membrillo (Gustavia superba) / guanabana toreta (Annona purpurea) / jobo (Spondias mombin) / mamey (Mammea americana) / carotenoids / HPLC-DAD-APCI-MS

Résumé - Étude de la composition des fruits du membrillo (Gustavia superba), de l'atier (Annona purpurea), du prunier mombin (Spondias mombin) et de l'abricotier des Antilles (Mammea Americana). Introduction. Nombreux sont les fruits tropicaux à fort potentiel pour la santé en fonction de la présence de substances phytochimiques bioactives. Les bases de données sur la composition des aliments naturels sont des sources d'information de première importance pour caractériser la diversité alimentaire naturelle et ses propriétés nutritionnelles. L'objectif de cette étude est de décrire, pour la première fois, la composition en caroténoïdes natifs des fruits de quatre espèces tropicales natives au Panama. Matériels et méthodes. Les fruits récoltés à pleine maturité au Panama ont été analysés par méthode HPLC-DAD-APCI-MS après extraction des caroténoïdes à l'acétone. Résultats et discussion. La composition en caroténoïdes n'avait jamais été signalée auparavant pour deux espèces étudiées, le membrillo (Gustavia superba) et l'atier (Annona purpurea). Dans les fruits du membrillo, 5 caroténoïdes différents ont été détectés ; le contenu en caroténoïdes totaux a atteint 318,6 $\mathrm{g} \mathrm{mg}^{-1}$ de poids frais (fw), avec du $\beta$-carotène en forte abondance relative (75,3\%). Dans les fruits de l'atier, 11 caroténoïdes différents ont été détectés; la teneur en caroténoïdes totaux était de $48,3 \mu \mathrm{g} \mathrm{g}^{-1} \mathrm{fw}$, avec $\beta$-carotène et zéaxanthine majoritaires (26,9\% et $27,5 \%$ respectivement). Dans les fruits du prunier mombin (Spondias mombin), 11 caroténoïdes différents ont été détectés; la teneur en caroténoïdes totaux était de $45,8 \mu \mathrm{g} \mathrm{g}^{-1} \mathrm{fw}$, comprenant $\beta$-cryptoxanthine, $\alpha$-carotène et $\beta$-carotène à des teneurs relatives de $25,4 \%, 10,5 \%$ et $8,5 \%$, respectivement.

\footnotetext{
^ Corresponding author: dgiuffrida@unime.it
} 
Dans les abricots des Antilles (Mammea americana), 16 caroténoïdes différents ont été détectés ; la teneur en caroténoïde totale était de 145,2 $\mathrm{g}^{-1} \mu \mathrm{g}$ fw, composée en particulier de 10 diesters différents de l'acide gras violaxanthine, dont deux isomères cis et trans ont été déterminés. Conclusion. La consommation des fruits des espèces étudiées devrait être encouragée à la fois localement et à l'étranger, en raison de la présence avérée de ces composés phytochimiques bénéfiques pour la santé.

Mots clés : Panama / membrillo (Gustavia superba) / atier (Annona purpurea) / prunier mombin (Spondias mombin) / abricotier des Antilles (Mammea americana) / caroténoïdes / HPLC-DAD-APCI-MS

\section{Introduction}

The use of plant phytochemicals has recently extended from the traditional use as specific therapeutic medicinal agents into other areas, especially nutraceutical and functional foods. Given that plant foods are still a major component of most diets worldwide, the greatest significance of phytochemicals derives from their role in human diets and health. The knowledge on the phytochemical composition of tropical fruit deserves greater attention; in fact, tropical fruit consumption is starting to moderately increase in domestic and international markets. Food composition databases are crucial although neglected sources of information relative to natural food biodiversity and nutritional properties [1,2].

Several tropical fruits may have great health potential due the possible presence of bioactive phytochemicals. Some studies have shown that antioxidants are more active when they are consumed naturally in food rather than as supplements $[3,4]$. Taking into account the modern and safer methods of food storage and transportation, and the general public awareness of the potential benefits of a diet rich in healthy fruit, the consumption of fruit containing "beneficial" phytochemicals should be promoted both for the local people and also worldwide. Our research group recently started a research project aimed at the characterization of the native carotenoid composition in tropical fruit, which may have great health potential due the possible presence of these bioactive phytochemicals.

Carotenoids belong to a nutritionally important family of phytochemicals [5-12]. Carotenoids are tetraterpenoids, either carotenes or xanthophylls; this last group is, in nature, often esterified by fatty acids. The study of carotenoids in natural matrices is usually carried out after a saponification (alkaline hydrolysis) step used to facilitate the carotenoid analysis because it releases the xanthophylls, removes the lipids and destroys the chlorophylls. However, saponification may have some severe drawbacks such as degradation processes [13-16]. Thus, for a better carotenoid profile evaluation in natural matrices and in order to provide valuable nutritional information, it would be more relevant to investigate the carotenoid profiles in unsaponified (native) samples [17]. Investigating both the profiles of free carotenoids and esterified xanthophylls would also take into consideration the fact that carotenoid esters are commonly present in natural matrices, and therefore in our diet, and that the esterification influences both the stability of pigments in plant tissues [18-20] and pigment bioavailability in the human body [21]. Moreover, carotenoid stability is influenced by their own structure and by the nature of xanthophyll esterification [22,23]. Esterification is a key step in xanthophyll accumulation in natural products: for instance, it enhances carotenoid liposolubility. Moreover, diesters are reported to be more stable than mono-esters and free xanthophylls [24].

There is a limited number of studies on saponified extracts of tropical fruit [25-27], and one survey dealing with Amazonian fruit [28]. In Panama several fruit species have not yet been considered for their intact carotenoid composition. Following our first study on the intact carotenoid profile of some tropical fruits [29], the objective of this study was to report for the first time on the intact carotenoid profile of membrillo (Gustavia superba Berg), guanabana toreta (Annona purpurea Moc. and Sessé), jobo (Spondias mombin L.) and mamey (Mammea americana L.) fruits from Panama. The specific objectives consisted of updating the databases on tropical fruit chemical composition, improving the information on esterification of xanthophylls, and highlighting the nutritional and economic value of local resources by promoting the utilization of these fruits, both locally and abroad. The carotenoid profile, native or saponified, has never been previously reported for two of the investigated fruit species, membrillo and guanabana toreta.

\section{Materials and methods}

In all investigations on carotenoids present in natural matrices, one must always take into consideration that the carotenoid content is influenced by several factors, biotic and abiotic. For example, it generally increases during fruit maturation and ripening, and it is affected by genotype, geographical area, type of soil and climatic conditions [30]. Panama has a tropical climate, with uniform high temperature and high relative humidity during the year, with a rainy season from April to December. The fruits studied in this work were collected in the Panama countryside, but they can also be found in other tropical areas, and they are typically consumed by the local people, although some processes of marketing are just emerging thanks to their health-related benefits.

\subsection{Chemicals}

The reagents and solvents used were of analytical or HPLC grade and were obtained from Sigma-Aldrich (Milan, Italy). $\beta$-carotene, lycopene, $\beta$-cryptoxanthin, lutein, zeaxanthin, lutein-di-palmitate and physalein were obtained from Extrasynthese (Genay, France); violaxanthin and phytoene were obtained from CaroteNature (Ostermundigen, Switzerland). 


\subsection{Sample collection}

All fruits were gathered during the period February 2012 through May 2013. About $2.5 \mathrm{~kg}$ each of fully mature fruit of membrillo, guanabana toreta and jobo were collected directly from twelve different trees of each species located in various areas in the State of Panama (latitude $7^{\circ}-10^{\circ} \mathrm{N}$, longitude $77^{\circ}-$ $83^{\circ} \mathrm{W}$ ) (figure 1). About $2.5 \mathrm{~kg}$ of fully mature fruit of mamey were purchased in local markets in Panama (figure 1).

- Membrillo (Gustavia superba Berg) is a tree belonging to the Lecythidaceae family, and is not widely known outside its native range from Equator to Panama. The trunk is 5$10 \mathrm{~m}$ high with leaves radiating from the top like palms. Its fruit bear a rounded pear shape and may contain up to four seeds embedded in a yellow-orange-colored edible pulp (figure 1) [31].

- Guanabana toreta (Annona purpurea Moc. and Sessé) is a plant belonging to the Annonaceae family, and it is fairly obscure among Annonas. It is a small to medium tree up to $10 \mathrm{~m}$ high. The fruit is rounded, with a diameter of $15-20 \mathrm{~cm}$, covered with a hard skin bearing hooklike projections. The yellow to orange pulp contains many seeds (figure 1) [31].

- Jobo (Spondias mombin L.) is a tree of the Anacardiaceae family. The mature fruit of the size of a lemon has a leathery skin and a thin layer of pulp. The fruit pulp is either eaten fresh or turned into juice or jam. Its juice is traditonally used as a febrifuge and diuretic (figure 1) [32].

- Mamey (Mammea americana L.) is a tree belonging to the Clusiaceae family, and is often confused with the mamey sapote tree (Pouteria sapota) whose fruit is also called mammee or mamey. The mamey tree is confined to tropical or subtropical climates; about $10-15 \mathrm{~m}$ high, it can reach $25 \mathrm{~m}$ height and is similar in appearance to the southern magnolia (Magnolia grandiflora L.). Mamey fruit is round or slightly irregular and has an orange pulp (figure 1) [33].

The samples were prepared by mixing the edible part of several fruits of the same species and three samples of each fruit mix were analyzed in triplicate.

\subsection{Carotenoid extraction}

Carotenoids were extracted from the fresh fruits according to Rodriguez-Amaya [34]. The edible part of fruits (10 g each) was mixed with $1 \mathrm{~g}$ sodium bicarbonate, homogenized, and extracted with acetone until color disappearance. The extract was reduced to about $25 \mathrm{~mL}$ in a rotary evaporator, and then a mixture of ether and hexane (1:1) and water was added. The upper phase was evaporated to dryness and the residue was solubilized in $2 \mathrm{~mL}$ methanol/MTBE (1:1 v/v) before HPLC analysis. All the laboratory operations were carried out under dim yellow light to avoid carotenoid modifications. The extracts were kept at $-20{ }^{\circ} \mathrm{C}$.

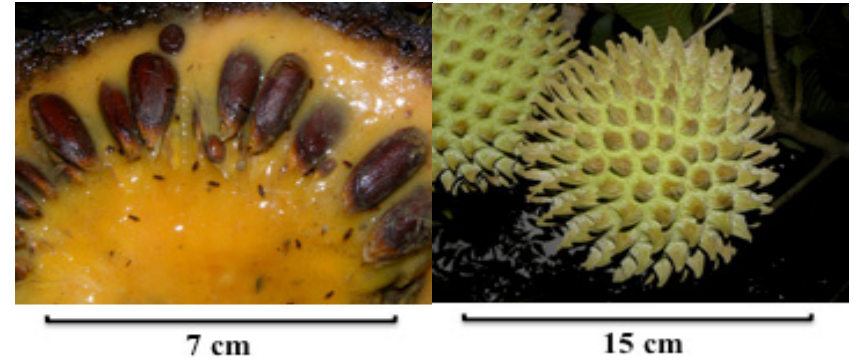

(a)

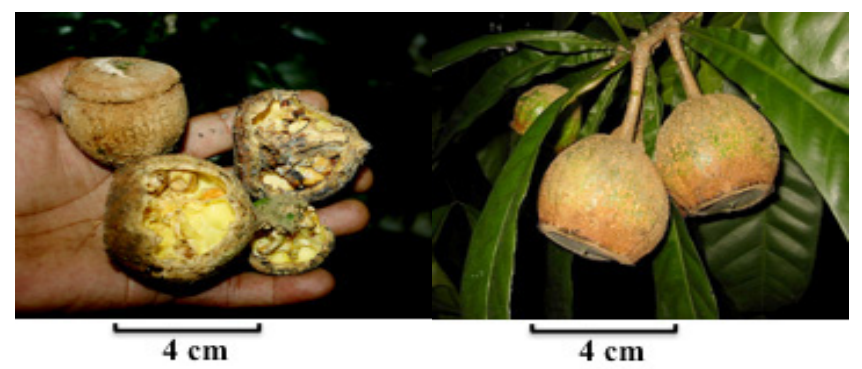

(b)

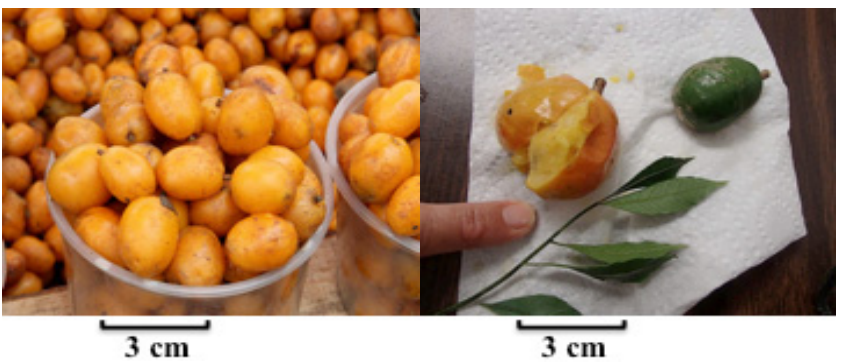

(c)

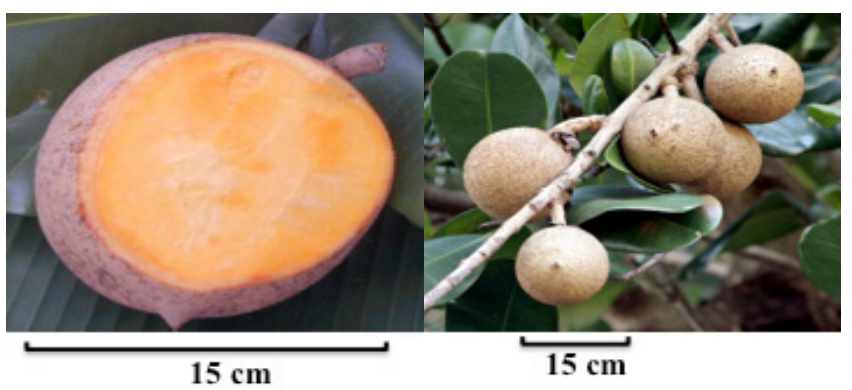

(d)

Figure 1. Corresponding morphology of the studied fruit species from Panama: (a) Guanabana toreta (Annona purpurea), (b) Membrillo (Gustavia superba), (c) Jobo (Spondias mombin), (d) Mamey (Mamea americana).

\subsection{Total carotenoid content}

The total carotenoid contents were determined by spectrophotometry, according to Rodriguez-Amaya [34] and Britton [35]. Briefly, the carotenoid extracts were dried under vacuum and then solubilized in an appropriate amount of solvent; the absorbance was measured at $450 \mathrm{~nm}$, and the $\mathrm{A}_{1 \mathrm{~cm}}^{1 \%}$ value of 2,500 was used. Taking into consideration the 
Table I. UV-Vis and mass spectrometer (MS) coupled to APCI (+) and APCI (-) information and identification of the carotenoids found in native membrillo extracts, and their relative abundance based on peaks areas recorded at $450 \mathrm{~nm}( \pm \mathrm{SD})$. Three different fruit samples were analyzed in triplicate.

\begin{tabular}{lllll}
\hline ID & Identification & UV-Vis maxima & MS data APCI (+) e (-) & Relative abundance (\%) \\
\hline 1 & Neoxanthin & $418,442,466$ & $601(+) ; 600(-)$ & $1.2 \pm 0.3$ \\
2 & $(13 Z) \beta$-carotene & $337,443,468$ & $537(+) ; 536(-)$ & $5.1 \pm 1.1$ \\
3 & $\beta$-carotene & 452,478 & $537(+) ; 536(-)$ & $75.3 \pm 6.8$ \\
4 & $(9 Z) \beta$-carotene & $339,445,472$ & $537(+) ; 536(-)$ & $4.3 \pm 1.2$ \\
5 & Violaxanthin-C16:0,C16:0 & $414,435,465$ & $1077(+) ; 821(+) ; 565(+) ; 1076(-) ; 820(-)$ & $2.2 \pm 08$ \\
\hline
\end{tabular}

Table II. UV-Vis and MS APCI (+) and APCI (-) information and identification of the carotenoids found in native guanabana toreta extracts, and their relative abundance based on peaks areas recorded at $450 \mathrm{~nm}( \pm \mathrm{SD})$. Three different fruit samples were analyzed in triplicate.

\begin{tabular}{lllll}
\hline ID & Identification & UV-Vis maxima & MS data APCI (+) e (-) & Relative abundance (\%) \\
\hline 1 & Mutatoxanthin & $406,427,451$ & $585(+) ; 584(-)$ & $4.4 \pm 1.3$ \\
2 & Zeaxanthin & $426,451,478$ & $569(+) ; 568(-)$ & $27.5 \pm 3.2$ \\
3 & $\beta$-carotene-5,8-epoxy & $406,427,453$ & $553(+) ; 552(-)$ & $3.1 \pm 0.8$ \\
4 & $(13 Z) \beta$-carotene & $337,443,468$ & $537(+) ; 536(-)$ & $6.2 \pm 1.2$ \\
5 & $\beta$-carotene & 452,478 & $537(+) ; 536(-)$ & $26.9 \pm 2.8$ \\
6 & $(9 Z) \beta$-carotene & $339,445,472$ & $537(+) ; 536(-)$ & $3.4 \pm 1.2$ \\
7 & $\beta$-cryptoxanthin-C12:0 & 451,478 & $735(+) ; 535(+) ; 734(-)$ & $1.4 \pm 0.7$ \\
8 & Zeaxanthin-C12:0,C12:0 & 451,478 & $933(+) ; 733(+) ; 533(+) ; 932(-) ;$ & $1.1 \pm 0.7$ \\
9 & Lutein-C12:0,C12:0 & 445,470 & $933(+) ; 733(+) ; 533(+) ; 932(-) ; 732(-)$ & $0.6 \pm 0.1$ \\
10 & Zeaxanthin-C12:0,C14:0 & 451,478 & $961(+) ; 733(+) ; 533(+) ; 960(-) ; 760(-)$ & $0.2 \pm 0.06$ \\
11 & Lutein-C12:0,C14:0 & 444,469 & $961(+) ; 761(+) ; 733(+) ; 533(+) ; 960(-) ; 760(-)$ & $0.4 \pm 0.04$ \\
\hline
\end{tabular}

Table III. UV-Vis and MS APCI (+) and APCI (-) information and identification of the carotenoids found in native jobo extracts, and their relative abundance based on peaks areas recorded at $450 \mathrm{~nm}( \pm \mathrm{SD})$. Three different fruit samples were analyzed in triplicate.

\begin{tabular}{lllll}
\hline ID & Identification & UV-Vis maxima & MS data APCI (+) e (-) & Relative abundance $(\%)$ \\
\hline 1 & Lutein & $423,444,469$ & $551(+) ; 568(-)$ & $7.2 \pm 2.2$ \\
2 & $\beta$-cryptoxanthin-5,6-epoxy & $423,445,473$ & $569(+) ; 568(-)$ & $1.8 \pm 0.9$ \\
3 & $(13 Z / 13$ 'Z) $\beta$-cryptoxanthin & $337,420,444,469$ & $553(+) ; 552(-)$ & $2.1 \pm 0.8$ \\
4 & Phytoene & 286 & $545(+) ; 544(-)$ & $1.3 \pm 0.4$ \\
5 & Zeinoxanthin & $420,444,470$ & $553(+) ; 552(-)$ & $9.2 \pm 1.9$ \\
6 & Phytofluene & $332,347,368$ & $543(+) ; 542(-)$ & $0.4 \pm 0.01$ \\
7 & $\beta$-cryptoxanthin & 451,478 & $553(+) ; 552(-)$ & $25.4 \pm 4.1$ \\
8 & $\alpha$-carotene & $423,445,473$ & $537(+) ; 536(-)$ & $10.5 \pm 2.2$ \\
9 & $\beta$-carotene & 452,478 & $537(+) ; 536(-)$ & $8.5 \pm 2.1$ \\
10 & $\beta$-cryptoxantin-C14:0 & 452,479 & $763(+) ; 535(+) ; 762(-) ; 534(-)$ & $2.2 \pm 1.1$ \\
11 & $\beta$-cryptoxantin-C16:0 & 451,479 & $791(+) ; 535(+) ; 790(-) ; 534(-)$ & $1.1 \pm 0.8$ \\
\hline
\end{tabular}

reference values suggested by Britton and Khachik [36], we classified the level of the individual carotenoid $x$ as very high for $x>20 \mu \mathrm{g} \mathrm{g}^{-1}$ and high for $5<x<20 \mu \mathrm{g} \mathrm{g}^{-1}$.

\subsection{HPLC-DAD-APCI-MS analysis}

A high-pressure liquid chromatography (HPLC) system (Shimadzu, Milan, Italy) equipped with photodiode array and mass spectrometer (MS) detectors, with an atmospheric pressure chemical ionization (APCI) interface, operating both in positive and negative ionization mode, was used. A YMC $\mathrm{C}_{30}$ column $(250 \times 4.6 \mathrm{~mm}-5 \mu \mathrm{m})$ was used and the eluent consisted of methanol/MTBE/water (78:20:2, v/v/v; eluent A) and methanol/MTBE/water, (8:90:2, v/v/v; eluent B), using the following gradient: 0 min 0\% B; 22 min $0 \% \mathrm{~B} ; 100$ min $100 \% \mathrm{~B}$;
$102 \mathrm{~min} 0 \% \mathrm{~B}$. The flow rate was $0.8 \mathrm{~mL} \mathrm{~min}^{-1}$ and the injection volume was $20 \mu \mathrm{L}$. The UV-Vis spectra were acquired in the range of 250-600 $\mathrm{nm}$. The MS was set as follows: scan, both APCI positive (+) and negative (-); nebulizing gas flow

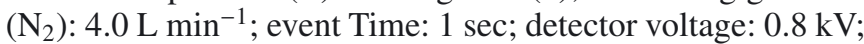
$\mathrm{m} / \mathrm{z}$ range: $350-1,200$; interface voltage: $4.5 \mathrm{kV}$; interface temperature: $350{ }^{\circ} \mathrm{C}$; CDL voltage: $0 \mathrm{~V}$; CDL temperature: $300{ }^{\circ} \mathrm{C}$; heat block: $300{ }^{\circ} \mathrm{C}$; Q-array: $0.0 \mathrm{~V}$; RF: $90 \mathrm{~V}$; sampling: $2 \mathrm{~Hz}$.

The qualitative evaluation was determined by comparison with the available standards, the consideration of the elution order of the different compounds, the UV-Vis spectra, the APCI-MS spectra and, where available, the literature information. The quantitative data reported in the tables (tables $I-I V$ ) as \% of relative abundance of each identified compound were calculated considering the respective peak areas in the recorded chromatograms at $450 \mathrm{~nm}$, and should be consid- 
Table IV. UV-Vis and MS APCI (+) and APCI (-) information and identification of the carotenoids found in native mamey (Mamea americana) extracts, and their relative abundance based on peaks areas recorded at $450 \mathrm{~nm}( \pm \mathrm{SD})$ Three different fruit samples were analyzed in triplicate.

\begin{tabular}{lllll}
\hline ID & Identification & UV-Vis maxima & MS data APCI (+) e (-) & $\begin{array}{l}\text { Relative } \\
\text { abundance }(\%)\end{array}$ \\
\hline 1 & Not identified & 445 & Not determined & $10.1 \pm 2.2$ \\
2 & Apo-12'-violaxanthal & 437 & $383(+) ; 382(-)$ & $0.7 \pm 0.06$ \\
3 & Zeaxanthin & $426,451,478$ & $569(+) ; 568(-)$ & $1.7 \pm 0.8$ \\
4 & Phytoene (+ not identified) & $276,286,297(+446)$ & $545(+) ; 544(-)$ & $8.1 \pm 1.8$ \\
5 & Phytofluene & $332,347,368$ & $543(+) ; 542(-)$ & $0.3 \pm 0.01$ \\
6 & Violaxanthin-C12:0,C12:0 & $418,439,469$ & $965(+) ; 765(+) ; 565(+) ; 964(-) ; 764(-)$ & $2.4 \pm 0.8$ \\
7 & cis-violaxanthin-C12:0,C12:0 & $321,412,435,464$ & $965(+) ; 765(+) ; 565(+) ; 964(-) ; 764(-)$ & $1.5 \pm 0.5$ \\
8 & Violaxanthin-C12:0,C14:0 & $418,439,469$ & $993(+) ; 793(+) ; 765(+) ; 565(+) ; 992(-) ; 764(-)$ & $2.7 \pm 0.8$ \\
9 & cis-violaxanthin-C12:0,C14:0 & $322,413,434,464$ & $993(+) ; 793(+) ; 765(+) ; 565(+) ; 992(-) ; 764(-)$ & $3.6 \pm 0.8$ \\
10 & Antheraxanthin-C12:0,C12:0 & $422,444,472$ & $949(+) ; 749(+) ; 549(+) ; 948(-) ; 748(-)$ & $1.5 \pm 0.6$ \\
11 & Violaxanthin-C12:0,C16:0 & $418,439,468$ & $1021(+) ; 803(+) ; 748(+) ; 565(+) ; 1020(-) ; 820(-)$ & $4.1 \pm 1.0$ \\
12 & cis-violaxanthin-C12:0,C16:0 & $322,413,435,465$ & $1021(+) ; 803(+) ; 748(+) ; 565(+) ; 1020(-) ; 820(-)$ & $3.1 \pm 0.9$ \\
13 & Violaxanthin-C12:0,C18:0 & $418,439,469$ & $1049(+) ; 849(+) ; 765(+) ; 1048(+) ; 848(-) ; 764(-)$ & $4.1 \pm 1.1$ \\
14 & cis-violaxanthin-C12:0,C18:0 & $321,413,435,464$ & $1049(+) ; 849(+) ; 765(+) ; 1048(+) ; 848(-) ; 764(-)$ & $1.7 \pm 0.7$ \\
15 & Violaxanthin-C16:0,C16:0 & $418,438,469$ & $1077(+) ; 821(+) ; 565(+) ; 1076(+) ; 848(-) ; 764(-)$ & $2.3 \pm 0.8$ \\
16 & cis-violaxanthin-C16:0,C16:0 & $322,414,436,466$ & $1077(+) ; 821(+) ; 565(+) ; 1076(+) ; 848(-) ; 764(-)$ & $1.6 \pm 0.4$ \\
\hline
\end{tabular}

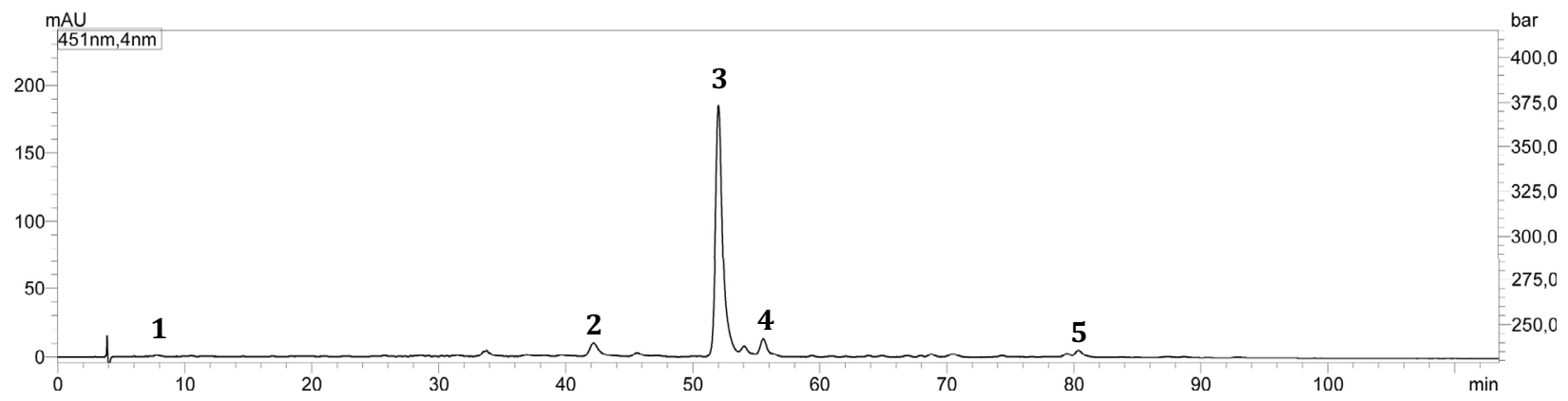

Figure 2. Chromatogram $(450 \mathrm{~nm})$ of membrillo carotenoid extracts, using a C30 column. For peak identification, see table I.

ered as orientative, since different carotenoids possess different extinction coefficients. Triplicate analyses were performed. Precision was assessed as RSD\% in terms of intra-day repeatability and intermediate precision (inter-day repeatability) of retention times and peak areas at a concentration of $1 \mathrm{mg} \mathrm{L}^{-1}$ of carotenoid standards. For this purpose, instrumental within-day repeatability was evaluated on three replicates of carotenoid standard solutions by performing three injections on the same day. The instrumental inter-day repeatability was calculated on five replicates of carotenoid standard solutions by performing three injections of each sample for five days. Precision in terms of intra-day repeatability was calculated providing $\mathrm{RSD} \%$ in the $1-4 \%$ range for peak areas and $2.5 \%$ for retention times $(n=6)$. The intermediate precision results were found to be $<2 \%$ for peak areas and $<2.5 \%$ for retention times $(n=10)$, confirming the good method precision.

\section{Results and discussion}

\subsection{Membrillo fruit}

Figure 2 shows the HPLC native carotenoid profile present in membrillo, and the related characterization data of the compounds are shown in table I, together with their spectroscopic information, and their relative abundance based on peak areas.
In membrillo, 5 different carotenoids were detected; the total carotenoid content was $318.6( \pm 8.2) \mu \mathrm{g} \mathrm{g}{ }^{-1}$ fresh weight (fw), with $\beta$-carotene showing a relative abundance of $75.3 \%$. Among the esterified xanthophylls, only the violaxanthin diester with palmitic acid was detected. This work showed that this membrillo fruit is a very rich source of provita$\min \mathrm{A}(\beta$-carotene), and should be promoted as a nutritious food for human health. Examples of other common tropical fruits with very high reported contents of $\beta$-carotene are mango (Mangifera indica L.), gac (Momordica cochinchinensis (Lour.) Spreng) and buriti (Mauritia flexuosa L.f.) [36]. The high $\beta$-carotene abundance relative to the total carotenoid content reported here for membrillo is particularly noteworthy, considering that, in some common vegetables such as spinach and carrots regarded as very good sources of $\beta$-carotene, the respective reported contents for $\beta$-carotene range from 33 to $397 \mu \mathrm{g} \mathrm{g}^{-1} \mathrm{fw}[37,38]$ for spinach and from 34 to $534 \mu \mathrm{g} \mathrm{g}^{-1}$ fw $[38,39]$ for carrots.

\subsection{Guanabana toreta fruit}

Figure 3 shows the HPLC intact carotenoid profile present in guanabana toreta, and the related characterization data of the compounds are shown in table II, together with the compound spectroscopic information and their relative abundance. 


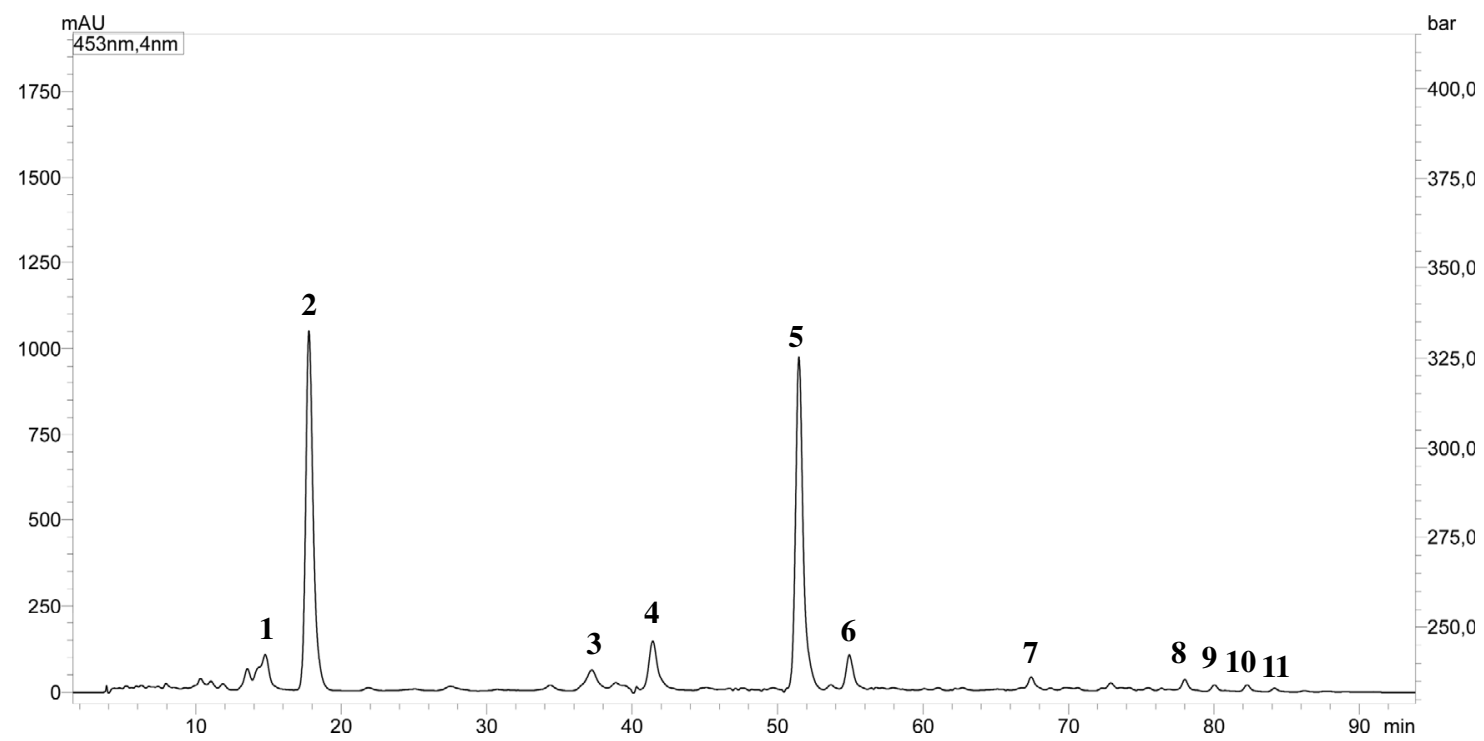

Figure 3. Chromatogram $(450 \mathrm{~nm})$ of guanabana toreta carotenoid extracts, using a C30 column. For peak identification, see table II.

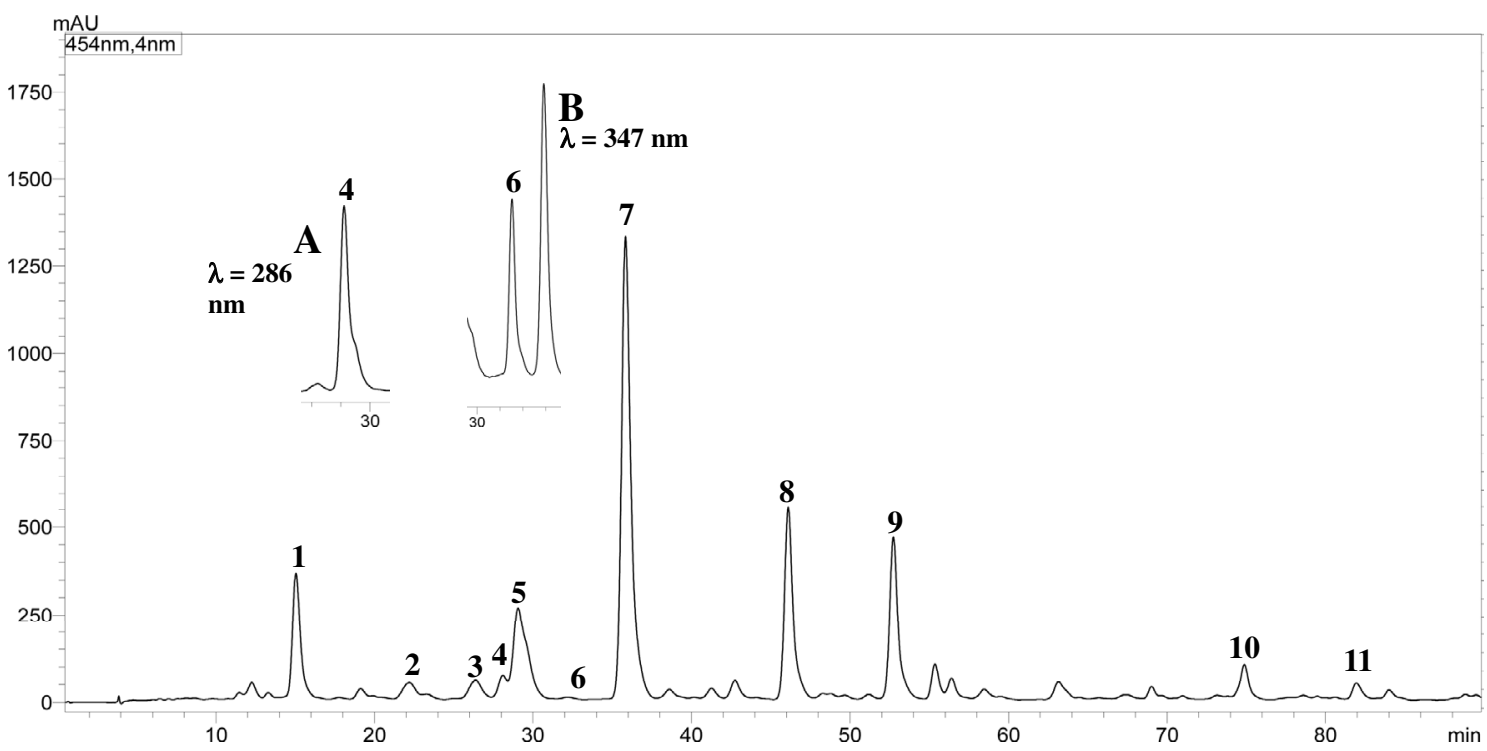

Figure 4. Chromatogram $(450 \mathrm{~nm})$ of Jobo carotenoids extract, using a C30 column. For peak identification, see table III. Insertions A and B show the peaks corresponding to phytoene $(4 ; \mathrm{Rt}=27.7 \mathrm{~min})$ and phytofluene $(6 ; \mathrm{Rt}=33.3 \mathrm{~min})$ recorded at their specific absorbance wavelenghts.

In guanabana toreta, 11 different carotenoids were detected; the total carotenoids content was $48.3( \pm 2.2) \mu \mathrm{g} \mathrm{g}^{-1} \mathrm{fw}$, with $\beta$-carotene and zeaxanthin showing a relative abundance of $26.9 \%$ and $27.5 \%$, respectively. The diesters of lauric and myristic acids with both lutein and zeaxanthin were detected. The utilization of this fruit should be promoted considering the rich presence of valuable carotenoids such as zeaxanthin and $\beta$-carotene. Zeaxanthin has been correlated with the prevention of eye pathologies [40,41]. Buriti is another tropical fruit reported to have high zeaxanthin content [36].

\subsection{Jobo fruit}

Figure 4 shows the HPLC native carotenoid profile present in jobo, and the related compound characterization data are shown in table III, together with the compound spectroscopic information, and relative abundance.

In jobo, 11 different carotenoids were differentiated according to a combination of both UV-Vis and MS spectral data, elution order, available standards and various reports [42-44]. The total carotenoid content was $45.8( \pm 3.1) \mu \mathrm{g} \mathrm{g}^{-1} \mathrm{fw}$, with $\beta$-cryptoxanthin, $\alpha$-carotene and $\beta$-carotene showing a relative abundance of $25.4 \%, 10.5 \%$ and $8.5 \%$, respectively. $\beta$-Cryptoxanthin-5,6-epoxide and the mono-esters of myristic and palmitic acid with $\beta$-cryptoxanthin were also detected for the first time in jobo fruit samples. The total carotenoid content reported here is similar to the value reported by Tiburski [42], who analyzed saponified carotenoid extracts of jobo fruit samples from Brazil. This fruit is a good source of provitamin A carotenoids such as $\beta$-carotene, $\beta$-cryptoxanthin and 


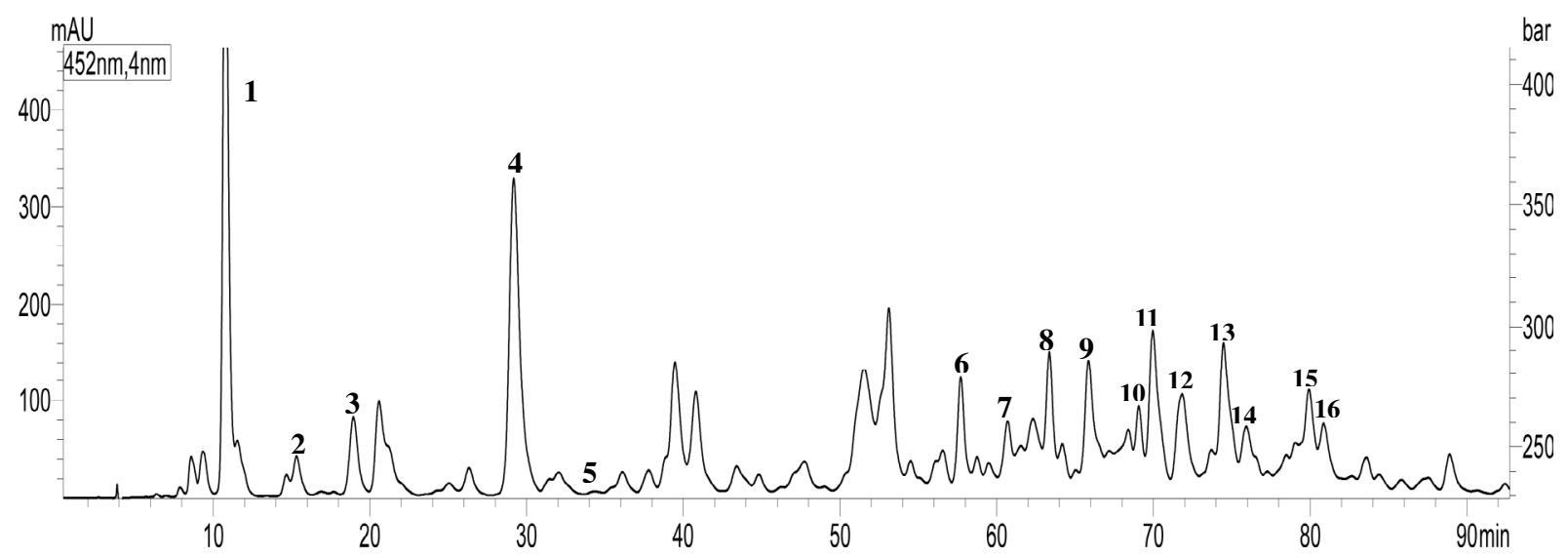

Figure 5. Chromatogram $(450 \mathrm{~nm})$ of mamey carotenoid extracts, using a C30 column. For peak identification, see table IV.

$\alpha$-carotene. $\beta$-Cryptoxanthin has recently been linked to osteoporosis prevention [45]. Lutein is also well represented in jobo. The joint presence of lutein and zeaxanthin is interesting, since lutein is highly assimilated into the eye macula where, together with zeaxanthin and the meso-zeaxanthin formed in situ from lutein conversion, may act against age-related macular degeneration $[40,41,46]$.

Phytoene and phytofluene were also detected during this work in jobo fruit at their respective UV-Vis absorbance values of $286 \mathrm{~nm}$ and $347 \mathrm{~nm}$ (figure 4). These two acyclic carotenoids were previously detected in jobo by Hamano [43], but were not reported by Tiburski [42]. Examples of other tropical fruits with a reported high content of $\beta$-cryptoxanthin are papaya and pitanga [36].

\subsection{Mamey fruit}

Figure 5 shows the HPLC intact carotenoid profile present in mamey, and the related compound characterization data are shown in table $I V$, together with the compound spectroscopic information, and relative abundance.

In mamey, the total carotenoid content was 145.2 $( \pm 4.8) \mu \mathrm{g} \mathrm{g}^{-1} \mathrm{fw}$, which was more than double the value reported by de Rosso and Mercadante [28] for saponified carotenoid extract of mamey fruit from Brazil. In our study, 16 different carotenoids were detected (figure 5). In particular, peak number 1 showed a UV-Vis absorbance at $445 \mathrm{~nm}$ but was not identified; peak number 4, considering its UV-Vis and APCI (+) MS spectra and elution order, was partially attributed to phytoene which coeluted with another non-identified compound whose mass spectrum was not clear, and whose UV-Vis absorbance was at $446 \mathrm{~nm}$.

(all-E)-Phytoene is a biosynthetic acyclic carotenoid intermediate, which is usually present in small amounts in plants because it normally undergoes desaturation. Instead, its cis isomer (15Z)- phytoene can accumulate in plants. Phytofluene was also detected in this work in mamey. Recently, evidence for the possible involvement of phytoene and phytofluene in health-promoting biological action has been accumulating [47]. Zeaxanthin was detected in mamey for the first time. Apo-12'-violaxanthal was identified in our study in mamey fruit from Panama, in agreement with the report by de Rosso and Mercadante [28] on saponified carotenoid extract of mamey fruit from Brazil. This apocarotenoid may be derived from oxidative degradation of violaxanthin. Interestingly, 10 different violaxanthin fatty acid diesters, of both cis and trans isomers, were determined for the first time in this fruit. Previously, Ornelas-Paz et al. [48] reported the presence of some violaxanthin esters in mango fruits. The applied HPLCPAD-MS methodology enabled a more selective analysis of violaxanthin fatty acid esters than reported previously. Although the violaxanthin esters showed similar UV-Vis spectra (see $t a$ ble IV), the APCI-MS detector enabled the identification of both the pseudomolecular ion and the ion fragments formed in the APCI source from the losses of the fatty acids esterified in the molecules, as shown in figure $6 \mathrm{~A}$ for the peaks corresponding to violaxanthin-laureate-palmitate $\left(\mathrm{C}_{12: 0}, \mathrm{C}_{16: 0}\right)$, and in figure $6 B$ for violaxanthin-di-palmitate $\left(\mathrm{C}_{16: 0}, \mathrm{C}_{16: 0}\right)$. For example, for violaxanthin-laureate-palmitate $\left(\mathrm{C}_{12: 0}, \mathrm{C}_{16: 0}\right)$, it can be observed (figure 6A) how the protonated molecular ion [M $+\mathrm{H}]^{+}$at $m / z, 1021$ is present, together with the fragment ion at $m / z 1003$ corresponding to the loss of one molecule of water, and the fragment ions at $\mathrm{m} / \mathrm{z} 803$, at $\mathrm{m} / \mathrm{z} 748$ corresponding to the loss of, respectively, lauric acid and palmitic acid from the fragment ion at $m / z 1003$. The fragment ion at $m / z$ 565 corresponding to the loss of both fatty acids from the protonated molecular ion $[\mathrm{M}+\mathrm{H}]^{+}$at $m / z 1021$ can also be observed. For violaxanthin-di-palmitate $\left(\mathrm{C}_{16: 0}, \mathrm{C}_{16: 0}\right)$ (figure $\left.6 \mathrm{~B}\right)$, the protonated molecular ion $[\mathrm{M}+\mathrm{H}]^{+}$at $m / z 1077$ is present as the main ion, and fragment ions at $m / z 821$ and at $m / z 803$ are present corresponding, respectively, to the loss of palmitic acid from the protonated molecular ion $[\mathrm{M}+\mathrm{H}]^{+}$at $m / z 1077$ and of palmitic acid from the ion $[\mathrm{M}+\mathrm{H}-18]^{+}$at $m / z 1059$. Moreover, the fragment ion at $m / z 565$ is also present, corresponding to the loss of both fatty acids from the protonated molecular ion $[\mathrm{M}+\mathrm{H}]^{+}$at $m / z 1077$.

Interestingly, $\beta$-carotene was not detected in our studied mamey fruit, which, instead, was reported as the main carotenoid present in saponified carotenoid extracts of mamey fruit from Brazil [28]. Whether the difference arises from genetic factors or other factors such as the environmental and geographic conditions needs to be further investigated. Furthermore, there is no available information in the literature about 

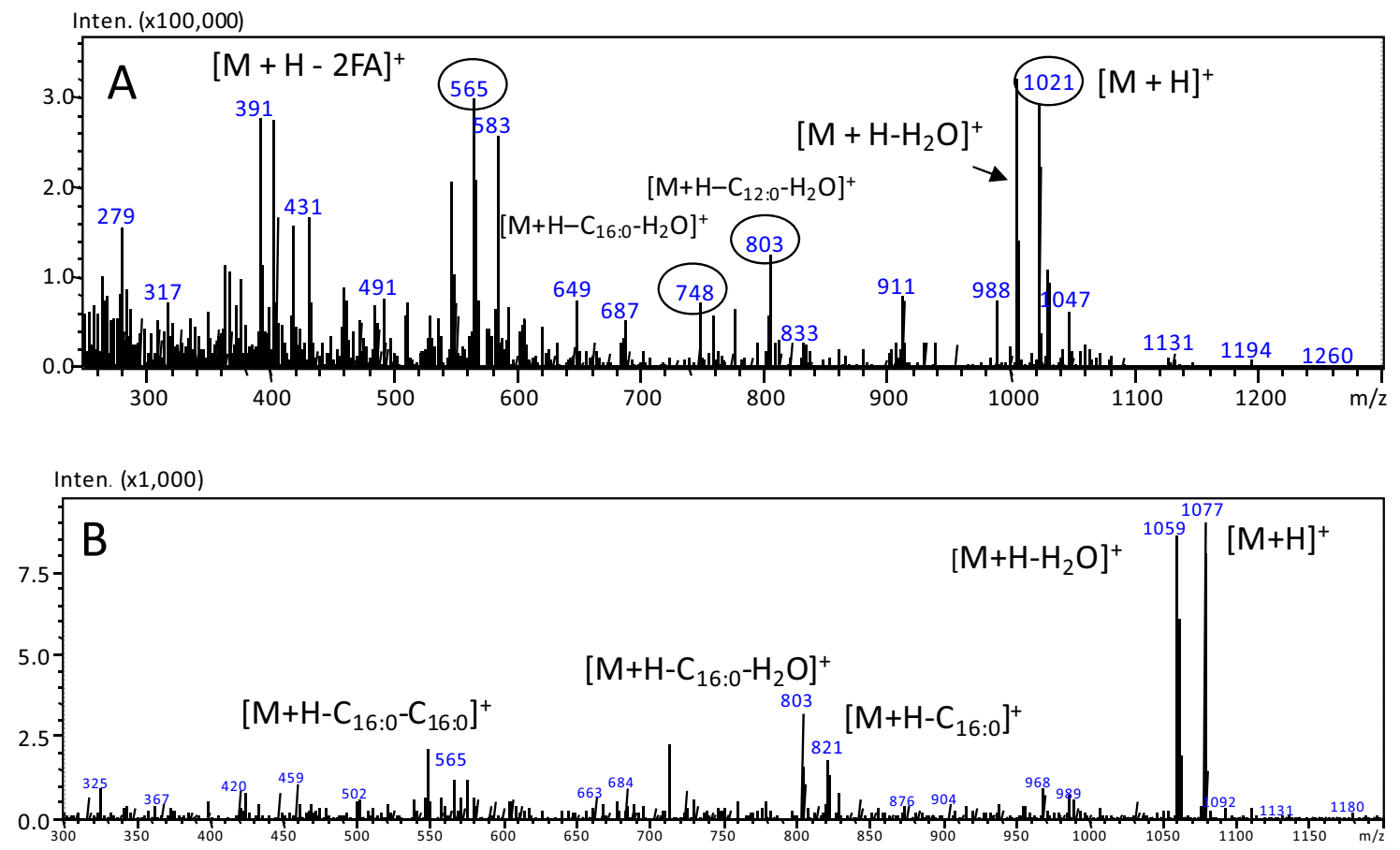

Figure 6. Example of identification, in native mamey carotenoids extract, of different carotenoid esters including the same xanthophyll, based on the APCI (+) MS spectral properties. The compounds present similar UV/Vis spectra (see table IV). MS spectra and identification: A, violaxanthin-laureate-palmitate (C12:0, C16:0); B, violaxanthin-di-palmitate (C16:0, C16:0).

the unsaponified carotenoid composition of the four investigated fruit species to be used for comparison of our results.

\section{Conclusions}

The native carotenoid profiles of four tropical fruit species from Panama were generated for the first time. Each species showed a typical carotenoid profile. Nutritionally important carotenoids were detected in all of them, thus emphasizing the importance of their promotion in the human diet for both the local people and exports. New data for nutritional databases were provided together with information that can be used for the elucidation of the different chemical pathways leading to the various carotenoids identified in each of the studied fruit species. The information provided is useful for the food industry in order to evaluate the value of these fruits as new food ingredients. In particular, the carotenoid profiles (native or saponified) have never been reported previously for two of the investigated fruits, membrillo (Gustavia superba) and guanabana toreta (Annona purpurea). Membrillo showed a very high $\beta$-carotene content and guanabana toreta showed high $\beta$-carotene and zeaxanthin contents, both considered important health-related carotenoids.

Moreover, new information on the carotenoid composition is provided for the jobo (Spondias mombin) fruit samples and, regarding the detailed data provided on the esterification of carotenoids in these fruit species, the extensive information about the fatty acids esterifying violaxanthin in mamey (Mammea americana) should be highlighted. In fact, the applied HPLC-PDA-MS methodology enabled the most selective analysis of violaxanthin fatty acids esters ever reported. Taking into account the modern and safer methods of food storage and transportation and the general public awareness of the potential health benefits of a diet rich in healthy fruit, the information provided here could also be used by the food industry in evaluating the value of these fruit species in a broader market and as new ingredients in food with desirable nutritional properties.

\section{References}

[1] International Food Data Conference: A summary, Food Chem. 140 (2013) 399-401.

[2] Charrondière U.R., Stadlmayr B., Rittenschober D., Moiille B., Nilsson E., Medhammar E., Olango T., Eisenwagen S., Persijn D., Ebenk K., Nowak V., Du J., Burlingame B., FAO/INFOODS food composition database for biodiversity, Food Chem. 140 (2013) 408-412.

[3] Lichtenstein A.H., Russell R.M., Essential nutrients: food or supplements? Where should the emphasis be?, J. Am. Med. Ass. 294 (2005) 351-358.

[4] Shenkin A., The key role of micronutrients, Clinic. Nutr. 25 (2006) 1-13.

[5] Britton G., Liaaen-Jensen S., Pfander H., Carotenoids. Volume 5: Nutrition and Health. Birkhauser, Basel, Switzerland, 2009.

[6] Beutner S., Bloedorn B., Frixel S., Hernandez-Blanco I., Hoffman T., Martin H.D., Mayer B., Noack P., Ruck C., Schmidt M., Schulke I., Sell S., Ernst H., Haremza S., Seybold G., Sies H., Stahl W., Walsh R., Quantitative assessment of antioxidant 
properties of natural colorants and phytochemicals: carotenoids, flavonoids, phenols and indigoids. The role of $\beta$-carotene in antioxidant functions, J. Sci. Food Agric. 81 (2001) 559-568.

[7] Caris-Veyrat C., Antioxidant and prooxidant actions and stabilities of carotenoids in vitro and in vivo and carotenoid oxidation products, in: Socaciu C. (Ed.). Food Colorants, chemical and functional properties, CRC Press, Taylor \& Francis Group, Boca Raton, London, New York, 2008, pp. 177-192.

[8] Arab L., Steck S., Lycopene and cardiovascular disease, Am. J. Clin. Nutr. 71 (2000) 1691S-1695S.

[9] Nishino H., Tokuda H., Satomi Y., Masuda M., Bu P., Onozuka M., Yamaguchi S., Okuda Y., Takayasu J., Tsuruta J., Okuda M., Ichiishi E., Murakoshi M., Kato T., Misawa N., Narisawa T., Takasuka N., Yano M., Cancer prevention by carotenoids, Pure App. Chem. 12 (1999) 2273-2278.

[10] Snodderly M. D., Evidence for protection against age-related macular degeneration by carotenoids and antioxidant vitamins, Am. J. Clin. Nutr. 62 (1995) S1448-S1461.

[11] Krinsky N. I., Landrum J. T. Bone, R. A., Biologic mechanisms of the protective role of lutein and zeaxanthin in the eye, Ann. Rev. Nutr. 23 (1) (2003) 171-201.

[12] Krinsky,N.I., Johnson E. J., Carotenoid actions and their relation to health and disease, Molec. Aspect Med. 26 (2005) 459-516.

[13] Amorim-Carrilho K. T., Cepeda A., Fente C., Regal P., Review of methods for analysis of carotenoids, Trends Anal. Chem. 56 (2014) 49-73.

[14] Biehler E., Mayer F., Hoffmann L., Krause E., Bohn T., Comparison of 3 spectrophotometric methods for carotenoid determination in frequently consumed fruits and vegetables, J. Food Sci. 75 (2010) C55-C61.

[15] Muzhingi T., Yeum K. J., Russell R. M., Johnson E. J., Qin J., Determination of carotenoids in yellow maize, the effects of saponification and food preparations, Int. J. Vit. Nutr. Res. 78 (2008) 112-120.

[16] Davey M. W., Keulemans J., Swennen R., Methods for the efficient quantification of fruit provitamin A contents, J. Chrom. A 1136 (2006) 176-184.

[17] da Silva L. M. R., de Figueiredo E. A. T., Ricardo N. M. P. S., Vieira I. G. P., de Figueiredo R. W., Brasil I. M., Gomes C. L., Quantification of bioactive compounds in pulps and by-products of tropical fruits from Brazil, Food Chem. 143 (2014) 398-404.

[18] Fu H., Xie B., Fan G., Ma S., Zhu X., Pan S., Effect of esterification with fatty acid of [beta]-cryptoxanthin on its thermal stability and antioxidant activity by chemiluminescence method, Food Chem. 122 (2010) 602-609.

[19] Bunea A., Andrei S., Rugina D., Pintea A., Thermal and light stability of $\beta$-cryptoxanthin esters, in: Proceedings of the 7 th International Congress on Pigments in Food, Novara, Italy, 2013, pp. 170-173.

[20] Pintea A., Bunea A., Socaciu C., Effect of esterification on thermal stability and antioxidant activity of zeaxanthin, in: Proceedings of the 7th International Congress on Pigments in Food, Novara, Italy, 2013, pp. 174-177.

[21] Pérez-Gálvez A., Mínguez-Mosquera, M. I., Esterification of xanthophylls and its effect on chemical behavior and bioavailability of carotenoids in the human, Nutr. Res. 25 (2005) 631640.

[22] Perez-Galvez A., Minguez-Mosquera, M.I., Degradation of non-esterified and esterified xanthophylls by free radicals, Biochem. Biophys. Acta 1569 (2002) 31-34.
[23] Goda Y., Sakamoto S., Nakanishi T., Maitani T., Yamada T., Identification of monoesterified capsanthin in paprika (Capsicum annuum): the nature of esterification of capsanthin, Chem. Pharm. Bull. 43 (1995) 1248-1250.

[24] Biacs P., Czinkotai B., Hoschke, A., Factors affecting stability of coloured substances in paprika, J. Agric. Food Chem. 40 (1992) 363-367.

[25] Yahia E. M., Gutiérrez-Orozco F., Arvizu-de Leon C., Phytochemical and antioxidant characterization of mamey (Pouteria sapota Jacq. H.E. Moore \& Stern) fruit, Food Res. Int. 44 (2011) 2175-2181.

[26] Akter M. S., Oh S., Eun J. B., Ahmed M., Nutritional compositions and health promoting phytochemicals of camu-camu (Myrciaria dubia) fruit: A review, Food Res. Int. 44 (2011) 1728-1732.

[27] Isabelle M., Lee B. L., Lim M. T., Koh W. P., Huang, D., Ong, C. N., Antioxidant activity and profile of common vegetables in Singapore, Food Chem. 120 (2010) 993-1003.

[28] de Rosso V. V., Mercadante A. Z., Identification and quantification of carotenoids, by HPLC-PDA-MS/MS, from Amazonian fruits, J. Agric. Food Chem. 55 (2007) 5062-5072.

[29] Murillo E., Giuffrida D., Menchaca D., Dugo P., Torre G., Meléndez-Martinez A.J., Mondello, L., Native carotenoids composition of some tropical fruits, Food Chem. 140 (2013) 825-836.

[30] Hornero-Méndez D., Mínguez-Mosquera M. I., Xanthophyll esterification accompanying carotenoid overaccumulation in chromoplast of Capsicum annuum ripening fruits is a constitutive process and useful for ripeness index, J. Agric. Food Chem. 48 (2000) 1617-1622.

[31] Ross de Cerdas M. Las fruitas del paraiso, The fruits of paradise, San José, C.R.: Editorial de la Universidad de Costa Rica, 2003, $244 \mathrm{p}$.

[32] Morton, J. Yellow Mombin, in: Julia F. Morton (Ed.), Fruits of warm climates, Miami, FL, 1987, pp. 245-248.

[33] Gervais L., Lavigne C. Mamey (Mammea americana L.) in Martinique island: an inheritance to be developed, Fruits 62 (2007) 237-246.

[34] Rodriguez-Amaya D. B., A guide to carotenoid analysis in food, ILSI Press, Washington, DC, USA, 2001.

[35] Britton G., General carotenoids methods, Meth. Enzymol. 111 (1985) 113-148.

[36] Britton G., Khachik F., Carotenoids in Food, in: Britton G., Liaaen-Jensen S., Pfander H (Eds.) Carotenoids, Volume 5: Nutrition and Health, Birkhauser Basel, Switzerland, 2009, pp. 45-66.

[37] Grenado F. Carotenoid composition in raw and cooked Spanish vegetables, J. Agric. Food Chem. 40 (1992) 2135-2139.

[38] Lessin W. I., Catigani G. I., Schwartz S. J., Quantification of cis-trans isomers of provitamin A carotenoids in fresh and processed fruits and vegetables, J. Agric. Food Chem. 45 (1997) 3728-3735.

[39] Almeida L. B., Penteado, M. V. C., Carotenoids with provitamin A activity of carrots (Daucus carota L.) consumed in San Paulo, Brazil. Rev. Farm. Bioquim. Univ. S. Paulo 23 (1987) 133-137.

[40] Schalch W., Cohn W., Barker F. M., Kopcke W., Mellerio J., Bird A. C., Robson A. G., Fitzke F. F., van Kuijk F. J. G. M., Xanthophyll accumulation in the human retina during supplementation with lutein or zeaxanthin - the LUXEA (LUtein Xanthophyll Eye Accumulation) study, Arch. Biochem. Biophys. 458(2) (2007) 128-135. 
[41] Le M., Xiao-Ming L., Effects of lutein and zeaxanthin on aspects of eye health, J. Agric. Food Chem. 90(1) (2010) 2-12.

[42] Tiburski J.H., Rosenthal A., Deliza R., de Oliveira Godoy R. L., Pacheco S., Nutritional properties of yellow mombin (Spondias mombin L.) pulp, Food Res. Int. 44 (2011) 2326-2331.

[43] Hamano P. S., Mercadante, A. Z., Composition of carotenoids from commercial products of caja (Spondias lutea), J. Food Comp. Anal. 14 (2001) 335-343.

[44] de Carvalho J. M., Maia G. A., da Fonseca A. V. V., de Sousa Sueli Rodrigues P. H. M., Effect of processing on physicochemical composition, bioactive compounds and enzymatic activity of yellow mombin (Spondias mombin L.) tropical juice, J. Food Sci. Technol. (2013) 1-6.

[45] Yamaguchi M., Role of carotenoid $\beta$-cryptoxanthin in bone homeostasis, J. Biom. Sci. 19 (2012) 1-13.
[46] Krinsky N. I., Landrum J. T., Bone R. A., Biologic mechanisms of the protective role of lutein and zeaxanthin in the eye, Ann. Rev. Nutr. 23(1) (2003) 171-201.

[47] Melendéz-Martinez. A., Mapelli-Brahm P., Stinco C., Wang X.-D., A minireview on the colourless carotenoids phytoene and phytofluene. Are they invisible bioactive compounds? In Proceedings of the 7th International Congress on Pigments in Food, Novara, Italy, 2013, pp. 322-325.

[48] Ornelas-Paz J., Yahia E. M., Gardea-Bejar A., Identification and quantification of xanthophyll esters, carotenes, and tocopherols in the fruit of seven mexican mango cultivars by liquid chromatography-atmospheric pressure chemical ionization time of flight mass spectrometry [LC-(APcI+)-MS], J. Agric. Food Chem. 55(16) (2007) 6628-6635.

Cite this article as: Daniele Giuffrida, Dania Menchaca, Paola Dugo, Paola Donato, Francesco Cacciola, Enrique Murillo. Study of the carotenoid composition in membrillo, guanabana toreta, jobo and mamey fruits. Fruits 70 (2015) 163-172. 